\title{
Protected Cultivation of Flowers for Domestic and Export Market
}

\author{
Prabhjit Kaur* and R. K. Dubey \\ Department of Floriculture and Landscaping, Punjab Agricultural University, \\ Ludhiana, India \\ *Corresponding author
}

\section{A B S T R A C T}

\begin{tabular}{|l|}
\hline Ke y w o r d s \\
Carnation, \\
Floriculture, \\
Greenhouse, \\
Lillium, Rose \\
\hline Article Info \\
\hline Accepted: \\
10 September 2019 \\
Available Online: \\
10 October 2019 \\
\hline
\end{tabular}

The horticulture field is developing new technologies for the development of quality products with higher productivity. Only quality products come under export for the world. Under protected cultivation the high quality produce can be achieved. The protected cultivation is technique of crop cultivation when the micro climate of the plant body is controlled partially or fully as per requirement of plant growth. The different designs of greenhouses developed for crop production varied from $\mathrm{Hi}$-tech to shade net. In floriculture, India is emerging country but floriculture crops have high tendency for export. The demand of flowers has been increased as now day's people like to celebrate their occasions with flowers. The export of commercial flowers is emerging as the commercial flower productions under the protected conditions have emerged in India. The floriculture crops have high potential for per unit area than the other field crops so it is more profitable business. The floricultural commodities for export consists cut flowers, pot plants, cut foliage, seeds bulbs, tubers, rooted cuttings and dried flowers or leaves. The demand of cut flowers is increasing in domestic and international market. The important cut flower in the international trade is rose, carnation, chrysanthemum, gerbera, gladiolus, gypsophila, liastris, nerine, orchids, archilea, anthuriu, tulip, and lilies. The meet the demand floriculture crops like rose, gerbera, carnation, lily etc. are grown in green houses.

\section{Introduction}

The advent of green revolution results in higher production but after this the demand was for quality produce with quantity, and that was only possible with the provision of optimum climate to the crop which can exploit the greater potential of the plants. This demand results to grow plants under controlled environmental conditions and called as protected cultivation. Protected cultivation is a technique of crop cultivation when the micro climate of the plant body is controlled partially or fully as per requirement of plant growth. As the agricultural technologies are improving, the various new protected cultivation practices have been emerged. Different kinds of protected structures adopted, on the basis of different agro-climatic region of India and availability of resources. Green house, Plastic house, high poly tunnels, low poly tunnels, Cloth house, Net house, shade house etc. are different structures which are used under protected 
cultivation and also are now available for the production of cut flower and foliage. Low cost greenhouse technology developed for high quality flower production in hilly states of $\mathbf{J} \&$ K, Himachal Pradesh, Uttaranchal and North Eastern states. These structures are now used commercially for export of quality flower production in plains of Maharashtra \& Karnataka. Crops like rose, gerbera, carnation and lillum etc. can be successfully grown under protected cultivation for high quality. Nowadays flower cultivation in protected structure used as commercial agriculture for better quality and more profit. Qualities of flowers produced in these structures are mostly used for export.

For higher productivity there are two essential concepts, one is the improvement of the genetic material and another is maintenance of favorable environment. For full exploitation of any genetic material for yield potential it is necessary to provide a favorable environment to the crop. Crops like rose, chrysanthemum, gerbera, carnation and lilum etc. can be successfully grown under protected cultivation for high quality. The maximum area under green house production in India is 800 hectares (Sanwal, 2011). India exported 19726.57 MT of floricultural products to the world for the worth of Rs. 571.38 crores/81.94 USD millions in 2018-19 (APEDA, 2019). The maximum export from India was to United States. The share of cut flower export is 6.1 per cent among the whole export. Due to high demand of flowers India is also importing floricultural products from other countries. The maximum area under Green house cultivation is in the Netherlands which is followed by Italy and Germany.

Despite the availability of natural resources for successful flower cultivation, our share in world flower trade is meager because most of the cut flowers need to be grown under protected conditions to meet the quality control regimes of global trade and thus require high cost. In our country, as the most of our farmers are small and marginal. Due to high cost involved in installation and maintenance these farmers are not coming forward to take up the advantages of protected cultivation. But there is advantage of naturally ventilated lost cost polyhouses for the small and marginal farmers who wish to take up floriculture for more profit. The low cost polyhouse may open the new avenues for increasing the acreage under protected cultivation. The farmers can send their produce to the near by market (Ranjan et al., 2013).

Protecting the plant from biotic and abiotic stresses is known as protected cultivation. Protected cultivation can be defined as a cropping technique where the micro climate surrounding the plant body is controlled partially/ fully as per the requirement of the plant species grown during their period of growth. Before commencement of the advanced structures, simple structures were commonly used by nurserymen and growers to modify the environment of limited area. Amongst these structures are cold frames, hot beds, sash beds etc. These save the crop for limited period only i.e. few weeks to few months only. When conditions become favorable, these structures are removed. But now-a-days many permanent structures are also used for controlling the environmental conditions of plants.

\section{Green house}

A greenhouse structure covered with a transparent or translucent material which can be plastic material or glass, crops grown under the partially controlled environment. The size of the green house is from about $10 \mathrm{~m}^{2}$ to few hectares. Larger size green houses are usually for export oriented flowers production. 


\section{Advantages of green house}

Greenhouse cultivation has advantages over the open pollinated cultivation of crops as there is high productivity per unit area due to efficient use of resources like irrigation, fertilizers etc. The superior quality of flowers production due to protection from abiotic and biotic stress and flowers fetch high price in market. Off-season crops can be grown as per the demand in market and in greenhouse it is easy to control the pests and diseases. The more plant height, stem length, number of flowers, bud and flower diameter were observed in rose cultivars when grown in when grown in greenhouse as compared to open field (Ahmad et al., 2011). Under the protected cultivation the returns from per unit area are higher besides early cropping, enhanced crop duration and bio control of pest, weed and disease.

\section{Basic considerations for Greenhouse construction}

\section{Topography}

The site should be free from shade. The site must be at higher level than the surrounding area for adequate drainage facility. Soil $\mathrm{pH}$ should be 5.5 to 6.5 and EC between 0.5 to 0.7 $\mathrm{mS} / \mathrm{cm}$. Soil should be changed or sterilized after every 3 to 4 years to avoid soil pathogens.

\section{Accessibility}

Access roads to the greenhouse need to be large enough to handle large motor vehicle and machinery.

\section{Size}

The size of the greenhouse depends upon the availability of the land and access to market. The experienced farmers / entrepreneurs can go for larger size greenhouse depending upon operation and project costs. Whereas nonexperienced can start with a naturally ventilated greenhouse having minimum size of $100 \mathrm{~m}^{2}$. It requires less initial investment.

\section{Water}

The quality and quantity of water that is available to the site must be determined. $\mathrm{pH}$ of the irrigation water should be in the range of 5.5 to 7.0 and $\mathrm{EC}$ between 0.1 to $0.3 \mathrm{mS} / \mathrm{cm}$.

\section{Electricity}

Greenhouse required the regularly supply of electricity service. Electrical could be a disaster for a greenhouse.

\section{Orientation}

Correct orientation provides good environmental conditions in the greenhouse. The orientation of a greenhouse depends upon light intensity and direction \& speed of wind. Single span greenhouse should be orientated towards East-West and in case of multi-span for taking advantage of available sun-shine the orientation should be towards North - South direction. In naturally ventilated greenhouse, the ventilators should open on leeward side. Single span greenhouse should have a long axis perpendicular to wind direction to protect it from damage.

\section{Types of greenhouse}

Keeping in mind the Indian climatic conditions, two types of greenhouse considered. They are Naturally Ventilated and Greenhouse with Fan \& Pad Cooling System.

\section{Naturally ventilated greenhouse}

This type of greenhouse best suited for areas where temperature remains $15{ }^{\circ} \mathrm{C}$ to $30{ }^{\circ} \mathrm{C}$. It 
should have provision of efficient number of openings for ventilation. The percentage for ventilation will be up to $60 \%$ of the floor area depending on climate conditions. The openings may be side wall vent or roof vent or both to exchange air flow in the greenhouse. During the summer period the openings ensure efficient air movement and should be fully airtight during winter.

\section{Greenhouse with fan and pad cooling system}

This type of greenhouse best suited for hot dry climatic conditions like Northern plains where temperature goes above $30{ }^{\circ} \mathrm{C}$. The cool air entered into greenhouse through wet pad from one end of the wall, the warm air replaced by fans placed on the opposite end of wall. High temperature causes various damages to the plants such as flower shedding, poor flower quality, transpiration, leaf scorch, and low net photosynthesis due to increased respiration rate etc. It is important to maintain air temperature inside the greenhouse for better results.

\section{Green house heating}

The greenhouse heating system required during winters when temperature inside greenhouse falls down. There some methods to raise the temperature inside a green house, which is described below:-

1. Boiler - One or more boilers can installed in a greenhouse and steam or hot water pipes release heat in to various locations of greenhouse.

2. Unit heaters - These are forced-air heaters. A fan in the back of the unit heaters draws in greenhouse air, passing it over the exterior side of the tubes, and then out the front of the heater to the greenhouse environment again. The cool air passing over the hot metal tubes is warmed. Thus raising the temperature of the greenhouse.

3. Convective heaters - These heaters differ from unit. Fuel including wood, coal, oil, or gas is combusted in a fire box. The resulting hot fumes pass out through an exhaust pipe which is situated along the ground either between ground beds or beneath benches.

\section{Green house cooling}

The methods to lower the temperature in greenhouse during summers are:-

Effective ventilation - Removing air from inside the greenhouse and replacing with outside air. It affects the heat, water vapour and $\mathrm{CO}_{2}$ concentration in the polyhouse. Ventilation can be Natural -by wind or mechanical or induced - accomplished by using fans. The cold air enters from vents and warm air escapes from the top vent.

Shading - to prevent rise in temperature and reduce light intensity. Shading can be done in following ways:

a. Inside screen - horizontal screen below the roof. E.g. Aluminium net

b. Outside screen - screen over the polyhouse. E.g. shade net

c. White washing - white distemper or lime can be applied on the polythene.

Fan pad cooling systems - In this system water passed through a pad placed vertically on wall of greenhouse. On the opposite wall exhaust fans are placed. Warm air passed through wet pad and pushed outside from the other side. In this process water absorbs heat from surroundings and evaporates. 
Fog and Misting systems - The cooling rate of air increases as water droplet size decreases. The mist droplet size is 1000 microns and size of fog droplet is 40 microns. These droplets remain suspended in air while they evaporate to cool the air and this occurs without water condensation at surface of leaves.

\section{Climatic factors influencing plant growth}

The importance of climatic factors and its desired level influence physiological characteristics of crops in a greenhouse. Some basic requirements of major cut flowers are given below:

\begin{tabular}{|l|l|l|l|l|l|l|l|}
\hline Crop & $\begin{array}{l}\text { life } \\
\text { cycle } \\
\text { (years) }\end{array}$ & $\begin{array}{l}\text { Day } \\
\left({ }^{\mathbf{0}} \mathbf{C}\right)\end{array}$ & $\begin{array}{l}\text { Night } \\
\left({ }^{\mathbf{0}} \mathbf{C}\right)\end{array}$ & $\begin{array}{l}\text { Humidity } \\
(\mathbf{\%})\end{array}$ & $\begin{array}{l}\text { Light } \\
\text { Intensity } \\
(\mathbf{L u x})\end{array}$ & $\begin{array}{l}\mathbf{C O}_{2} \\
\text { conc. } \\
(\mathbf{p p m})\end{array}$ & $\begin{array}{l}\text { Water } \\
\text { requisite in } \\
\text { lit/day/sqm }\end{array}$ \\
\hline Rose & $6.5-7$ & $24-28$ & $18.5-20$ & $65-70$ & $\begin{array}{l}60000- \\
70000\end{array}$ & $800-1000$ & $5-7$ \\
\hline Gerbera & $2.5-3$ & $20-24$ & $18-21$ & $60-65$ & $\begin{array}{l}40000- \\
50000\end{array}$ & $800-1000$ & $4-6$ \\
\hline Carnation & $2-2.5$ & $16-20$ & $10-12$ & $60-65$ & $\begin{array}{l}40000- \\
50000\end{array}$ & $800-1000$ & $4-6$ \\
\hline Lilium & 1 & $20-25$ & $10-15$ & $60-65$ & $\begin{array}{l}30000- \\
40000\end{array}$ & - & $6-8$ \\
\hline
\end{tabular}

Zambre A (2011)

\section{Green house -lighting}

The LED is new technology for greenhouse production as it has advantages over traditional lights but the recently tested for the horticulture crops. The major advantage of LED is that it has high electricity use efficiency for example the blue LEDs were having only $11 \%$ efficiency in 2006 were reported $49 \%$ efficient to convert electrical energy into photo energy in 2011 (Mitchell et al., 2012).

\section{Cladding material}

The greenhouse must be covered with as clear a material to provide the maximum amount of sunlight for the plants. Fiberglass, Poly Film etc., is used for covering material in greenhouse. The two types of plastic films used cladding- single layer clear transparent UV stabilized film and specialty films like diffused, anti drip, anti-dust, anti-sulphur etc. The selection of the film would depend on the crops in the greenhouse and chemical treatments given during the production cycle.

\section{Framework for Various Types of Greenhouse}

The materials for the frame work of a greenhouse are based on structural strength, durability, and initial cost and maintenance costs. Steel framework has been used widely. Steel frame house may have redwood or aluminum roof and wall bars as well as ventilator sash. The roof wall bars and ventilating sash all are made of aluminum. The corrosion problem with aluminum is slight, and the does not require painting.

\section{Fertigation}

The application of fertilizers along with water through irrigation system is known as fertigation. Drip irrigation system is used for fertigation. Small mistake leads to deterioration of quality of cut flowers. Jagtap 
et al., (2012) investigated the effect of foliar application of micronutrients on growth and flowering of rose under polyhouse conditions. The treatment comprised of 0.1 to 0.3 per cent alone $\mathrm{ZnSO}_{4}, \mathrm{MnSO}_{4}, \mathrm{FeSO}_{4}$ and combination treatments. The results indicated that the vegetative growth found superior under 0.3 per cent $\mathrm{ZnSO}_{4}+0.3$ per cent $\mathrm{MnSO}_{4}+0.3$ per cent $\mathrm{FeSO}_{4}$. Foliar spray of 0.3 per cent $\mathrm{ZnSO}_{4}+0.3$ per cent $\mathrm{MnSO}_{4}+0.3$ per cent $\mathrm{FeSO}_{4}$ increased the flower yield and quality of flower.

\section{Basic fertilizer dose in $\mathrm{mmol} / \mathrm{L}$ for some of major cut flowers}

\begin{tabular}{|l|l|l|l|l|l|l|l|}
\hline Crop & $\mathbf{N}$ & $\mathbf{P}$ & $\mathbf{K}$ & $\mathbf{C a}$ & $\mathbf{M g}$ & $\mathbf{S O}_{\mathbf{4}}$ & $\mathbf{E C}$ \\
\hline Rose & 4.0 & 0.15 & 1.5 & 2.0 & 1.2 & 1.5 & 1.0 \\
\hline Gerbera & 4.0 & 0.15 & 1.5 & 2.0 & 1.2 & 1.5 & 1.0 \\
\hline Carnation & 4.0 & 0.15 & 1.5 & 2.5 & 1.2 & 1.5 & 1.2 \\
\hline Lilium & 3.0 & 0.15 & 1.3 & 1.8 & 1.0 & 1.3 & 0.9 \\
\hline
\end{tabular}

Zambre A (2011)

Commercial crops grown under protected cultivation

\section{Rose}

The planting time for rose is October December. The rose planted in greenhouse on raised beds distance between plants should be 17 X $45 \mathrm{~cm}$. With this planting distance the 7.5 plants $/ \mathrm{m}^{2}$ can be planted. In a greenhouse of size $560 \mathrm{~m}^{2}$ total 4200 plant required and $1008 \mathrm{~m}^{2}$ sized greenhouse total 7560 plants required. The major varieties for green house are Top secret, Bordeaux, Golden Gates, Grand Galla, First Red, Konfetti, Mercedez, Ravel, Noblesse, Vivaldi, Gold Strike. The yield in case of HTs is 100-150 Stems/sqm per year and in case of medium and small flowered varieties are 200 and 250-350 Stems/sqm per year respectively.

Ahmad et al., 2011, compare the growth and yield of five promising cut rose (Rosa hybrida L.) cultivars in two production systems viz. greenhouse and field conditions. All plant growth and physiological indices of the study between the two beds should be $50 \mathrm{~cm}$ wide. were higher in greenhouse grown plants as compared with field cultivated. Among cultivars, 'Rosy Cheeks' and 'Whisky Mac' had vigorous vegetative growth while 'Amalia' and 'Anjlique' produced higher flower yield of best quality than other cultivars compared in the study. Roses grown in greenhouse produced taller plants $(80.6 \mathrm{~cm})$ than grown in the field $(68.7 \mathrm{~cm})$. These results suggested that roses can be best grown in greenhouse due to controlled environmental conditions particularly temperature and relative humidity which triggered plant growth as compared with those grown in open field. The results revealed that greenhouse production can increase flower yield as compared with field cultivation.

\section{Carnation}

A rich sandy loam soil is considered best for carnations. The planting time for carnation is September - October. Carnations are planted on raised beds up to $20-30 \mathrm{~cm}$ height from ground. The top width of bed should be 100 $\mathrm{cm}$ and bottom width $110 \mathrm{~cm}$. The pathway Sterilization of beds may be done with 
Chloropicrin about 10-15 days before planting. Planting distance from plant to plant and from row to row is $15 \mathrm{~cm}$. with this planting distance the planting density is 20-30 plants $/ \mathrm{m}^{2}$. The flower yield is $300-400$ flower $/ \mathrm{m}^{2}$. Most promising varieties for standard types are Master, Tanga, Sonsara, Laurella, Solar, Dakar, Raggio di Sole, Cabaret and Bagatel, Cherrybag, Fantasia, Picaro, Ondelia, Sintonia, Macarena for spray types.

Khanna et al., (1986) in carnation, concluded that cultivar Red King were found to be promising with respect to yield as well as flower quality parameters and found suitable for commercial cultivation under naturally ventilated green house in mid hills of Kumaon Himalayas. Dalawai and Naik (2014) conducted an experiment to know the effect of organic manures, biofertilizers and inorganic fertilizers on economics and profitability in Carnation (Dianthus caryophyllus L.) cv. Soto. The economics of cultivation of Carnation for an area of $560 \mathrm{~m}^{2}$ under naturally ventilated pollyhouse was worked out for one year. The annual establishment and maintenance cost worked out to Rs. $1,22,773 / 560 \mathrm{~m}^{2}$.

\section{Lilium}

Bulbs are usually planted in plains during October to November and in hilly areas during April to May. The flowering time is January to Feb in plains and July to August in hilly areas. Lilies are usually grown on raised beds about $15 \mathrm{~cm}$ above the ground level and the maximum depth at which the bulb should be placed is $6-8 \mathrm{~cm}$ during winter and $8-10 \mathrm{~cm}$ during summer months. Light is very important factor. Lilies grow well under low light intensity. High light intensity during summer reduces the stem length hence 50\% shade nets should be used. Whereas low light intensity during winters leads to flower abortion and abscission so, supplemental light should be given during these months.

\section{Gerbera}

Varieties for green house are Julia, Natasha, Alcatraz, Havana, Faith, Dakota, Grizzly, Basic.

Magar et al., (2010) carried out a study to evaluate the performance of 28 genotypes of gerbera. The high yielding varieties Sonata, Esmara, Opium, Solem, Gucci, Diana, Naome, Martinque, and Maidemoselli were useful for obtaining higher returns under naturally ventilated polyhouse.

A raised bed is always preferred for planting of gerbera. After fumigation, the beds prepared with dimensions as bottom width $70 \mathrm{~cm}$, top width $-60 \mathrm{~cm}$, path width $-30 \mathrm{~cm}$ and height $-45 \mathrm{~cm}$. While planting gerbera plants, the crowns of plants should be $1-2 \mathrm{~cm}$ above the soil level.

Generally, two rows should be planted on one bed at $37.5 \mathrm{~cm}$ distance between the rows and $30 \mathrm{~cm}$ distance between the plants in one row. Planting can be done round the year but preferably during September-October. After plantation, maintain the humidity at $80-90 \%$ for 4-6 weeks to avoid desiccation of plants. The crop yields 2 stems / plant / month. Harvest starts from 3rd month of planting and continued up to two years. Under greenhouse condition, $175-200$ flowers $/ \mathrm{m}^{2} /$ year can be obtained.

In conclusion, the green house technology is mainly the capital intensive high investment required on equipment and infrastructure. Since capital cost is high due to high interest rate and consumers are less attuned to pay higher price for quality green house. However, with growing consciousness for quality and increasing demand for different 
produce, the viability of this technology is improving. Since the technology has potential of increasing yield with quality, it needs to be encouraged. With boom in retail sector of horticulture in India, there is a growing demand for high quality, specialty produce and thus protected cultivation will be playing a major role to meet the demand of specific variety or type of flower. Indian floriculture became corporate driven, which could sense the potential and scope the modern protected cultivation technology.

\section{References}

Ahmad, I., Khalid, M. S., Khan, M. A. and Saleem, M. 2011. Morphophysiological comparison of cut rose cultivars grown in two production systems. Pak J Bot. 43(6): 2885-90.

Agricultural and Processed food products Export Development Authority (APEDA). 2019. https://apeda.gov.in

Jagtap, H. D., Golliwar, V. J. and Thakre, S. A. 2012. Effect of foliar application of micronutrients on growth and flowering of rose under polyhouse conditions. The
Asian J Hort. 7: 25-27.

Magar, S. D., Warade, S. D., Nalge, N. A. and Nimbalkar, C. A. 2010. Performance of Gerbera (Gerbera jamesonii) under naturally ventilated polyhouse condition. Intern J Plt Sci. 5: 609-12.

Mitchell, C. A., Both, A. J., Bourget, C. M., Burr, J. F., Kubota, C., Lopez, R. G., Marrow, R. C. and Runkle, E. S. 2012. LEDs - The Future of Greenhouse Lighting. Chronica Horticulturae 52(1): 6-11.

Ranjan, P., Ranjan, J. K., Das, and Ahmed, N. 2013. High Value Flower Cultivation under Low Cost Greenhouse in NW Himalayas. Intern J Chem Tech Res. 5:789-94.

Sanwal, S. K., Patel, K. K., and Yadav, D.S. 2011. Vegetable production under protected conditions in NEH region: Problems and prospects, ENVIS Bulletin: Himalayan Ecology 12 (2).1-7.

Zambre, A. 2011. Quality parameters of media, Water and specifications for Micro Irrigation System under greenhouse cultivation. Floriculture Today 16: 30-34.

\section{How to cite this article:}

Prabhjit Kaur and Dubey, R.K. 2019. Protected Cultivation of Flowers for Domestic and Export Market. Int.J.Curr.Microbiol.App.Sci. 8(10): 1017-1024.

doi: https://doi.org/10.20546/ijcmas.2019.810.119 